\title{
GREAT NEWS FOR THE GREAT BARRIER REEF: TULLY RIVER WATER QUALITY
}

\author{
Robert M. Carter \\ Marine Geophysical Laboratory, James Cook University, \\ Townsville Qld. 4811, Australia \\ email: bob.carter@jcu.edu.au
}

\begin{abstract}
A prerequisite for meaningful environmental legislation is that it be based upon an adequate scientific understanding of the natural system to which it is applied. In 2003, the Australian Commonwealth and Queensland State governments introduced a Reef Water Quality Protection Plan, which aimed to "improve" water quality in river catchments adjacent to the Great Barrier Reef (GBR) and in nearby coastal waters. The Plan was introduced in the absence of any substantive evidence for regional degradation of GBR water quality. This paper reviews the available data regarding nutrient contents in the Tully River, north Queensland, which is cited as the best (available) evidence for human-related changes in nutrient export from $(G B R)$ catchments [1]. It is shown that the claim of human-related nutrient enrichment in the Tully River, and regionally, is without substance. No detectable trends in GBR water quality have occurred since systematic measurements were first started in the 1980s. Environmental policies that are based on mischievous claims of chimerical damage to the Great Barrier Reef damage the reputation of science as a tool for disinterested analysis, and provoke widespread cynicism in the community regarding the integrity of contemporary environmental politics.
\end{abstract}

Keywords: Great Barrier Reef, nutrient, environmental legislation, anthropogenic

\section{INTRODUCTION}

\section{The Reef Water Quality Protection Plan}

In August 2002, the Australian Commonwealth and Queensland State Governments adopted a Memorandum of Understanding to develop mechanisms to improve water quality and reduce deleterious water quality impacts on the Great Barrier Reef (GBR) marine park. Little more than a year later, in October 2003, the governments published a formal Reef Water Quality Protection Plan [2] to be applied to land catchments located adjacent to the GBR.

Studies undertaken in advance of this Plan included more than 20 years of intensive research by university and government scientists into water quality issues on the GBR, 
as summarised by Furnas [1], the review of this research by an appointed panel of expert scientists [3], and a further review of the research and its related economic implications by the Commonwealth Productivity Commission [4].

The main goal of the protection plan is stated as: halting and reversing the decline in water quality entering the Reef within 10 years, by:

- Reducing diffuse sources of pollutants in water entering the GBR, and

- Rehabilitating and conserving areas of the Reef catchment that have a role in removing water-borne pollutants (e.g. wetlands)

The aims of reducing sources of pollution, and of assisting landholders to adopt best land management practices, are worthy and of classic 'no regrets' nature. However, the ambition to halt and reverse the decline in water quality entering the reef is fundamentally unsound, for the very good reason that no regional decline in reef water quality from its natural state has ever been detected, despite intensive research towards that end. Therefore, and as is shown in this paper, a large part of the Plan is based upon faulty premises

\section{THE "NO PROBLEM EXISTS" CONSENSUS}

During 2003, and following earlier summaries by the Great Barrier Reef Marine Park Authority (GBRMPA) [5], two much-publicised reports [3, 4] and one book [1] were released on the topic of human environmental impact on the water quality of the Great Barrier Reef World Heritage Area (GBRWHA). These reports and one other paper contain, inter alia, the following statements:

Low phosphorus concentrations in the sediments (of the Moresby River estuary, Mourilyan) suggest that agricultural practices in the catchment and associated anthropogenic inputs are having little, if any, impact on the catchment, river and estuary.

[6] (Eyre, 1993)

Broadscale phytoplankton surveys in the GBR ... show biomass and species composition consistent with an unimpacted system. GBR waters generally show no indications of long-term elevated nutrient or chlorophyll levels or recent rises in mean concentrations.

[5] (GBRMPA, 2001)

Time series of water quality parameters in the ... Cairns sector between 1989 and 1994 are characterised by distinct temporal variability, but lack an overall temporal trend.

[5] (GBRMPA, 2001)

There is no conclusive evidence yet of water quality decline within the GBR lagoon or of any resulting damage to ecosystems, (though) there is circumstantial evidence. 
Changes in land use practice during the last 200 years may have altered the type, quantitity and frequency of discharges to the GBR. Both the materials involved in the change and the rate and timing at which those materials are transported to the GBR may be significant.

[3] (Baker, 2003, p. 29)

Our current inability to detect clear changes in water quality within the GBR lagoon and the capacity of nearshore reef communities to tolerate locally elevated levels of turbidity, sedimentation and nutrient availability ....., should not be grounds for complacency.

[1] (Furnas, 2003, p. 292)

In addition, a recent authoritative international summary of the health of the world's coral reefs reported that:

Australian .... reefs are predominantly in good condition .... (and) well protected from a relatively low level of stress from the small population that is not dependent on reefs for subsistence. These reefs have exceptionally high biodiversity, favoured by the massive size and diversity of habitats. An extensive system of marine protected areas has been implemented, the best known of these is the Great Barrier Reef Marine Park .... which is amongst the best studied coral reefs in the world, with probably the largest and most extensive monitoring program, which is used as model for projects elsewhere.

[7] Sweatman et al. (2002)

These sources - which summarise the work of hundreds of scientists, and are based on several thousand pages of submissions - are unanimous about one main conclusion, which is that no direct evidence exists for regional human-induced damage to the GBR, including any measurable decline in water quality. Should the ghost of Captain Cook sail north along the shelf again today, and even were he equipped with modern measuring instruments, he would be unable to detect any changes in the reef and its surrounding oceanography from when he first observed them in 1770.

You might say that that is great news. And - referring to some of the quotations above - of course all sorts of things may (or may not) be circumstantially possible, and yes, we don't want to be complacent. Mystifyingly, however, the very same reports that draw these caveats fail to highlight the fact that abundant direct evidence exists that the GBR is in excellent health. This has been established by many scientific studies and in a recent review by Starck [8], and is summarised authoritatively by Sweatman et al. [7]. The healthy reef continues to be seen daily through the eyes of the thousands of tourists who visit the most heavily human-impacted parts of the GBR each week and report glowingly on their experiences.

Instead of being celebrated and promulgated, the news that the GBR has not suffered regional damage from increasing tourism, agriculture or urban development has been obscured by a tornado of self-interested spin and pressure-group environmental politics [9]. 
A comprehensive summary of the issue of water quality on the GBR is provided by Furnas [1]. Furnas asserts (p.188) that the best evidence for human-related changes in nutrient export from (GBR) catchments comes from a 13-year record of nutrient concentrations in the lower Tully River. In this paper, I examine the Tully River record critically, and discuss it and related matters in some detail.

\section{CHANGES IN TULLY RIVER NUTRIENT CONCENTRATIONS, 1987-2000}

Recently, both the Commonwealth (Minister for the Environment Kemp) and State (Premier Beattie) governments have responded to letters from Queensland landholders who have requested information about the implementation of the new Reef Management Plan. In their response, the respective Ministers report the finding of scientists of a doubling of nitrate values in the Tully River .... over the last 13 years, which they cite as an example of loss of nutrients from agricultural lands.

The Tully River is located just north of Hinchinbrook Island, and drains eastward from the Great Dividing Range to the central Great Barrier Reef Coast. A dam on the uppermost reaches of the river has created the Koombooloomba Reservoir. The incised upper reaches of the river downstream of the dam (Fig. 1a), and the estuary and river mouth (Fig. 1c), are relatively unimpacted by human development. The middle stretch of the river, between where it exits the mountains and where it approaches the coast, is flanked by floodplains which are subject to high impact agricultural activity (Fig. 1b), including particularly sugar cane and banana plantations and beef cattle grazing land.

(a)

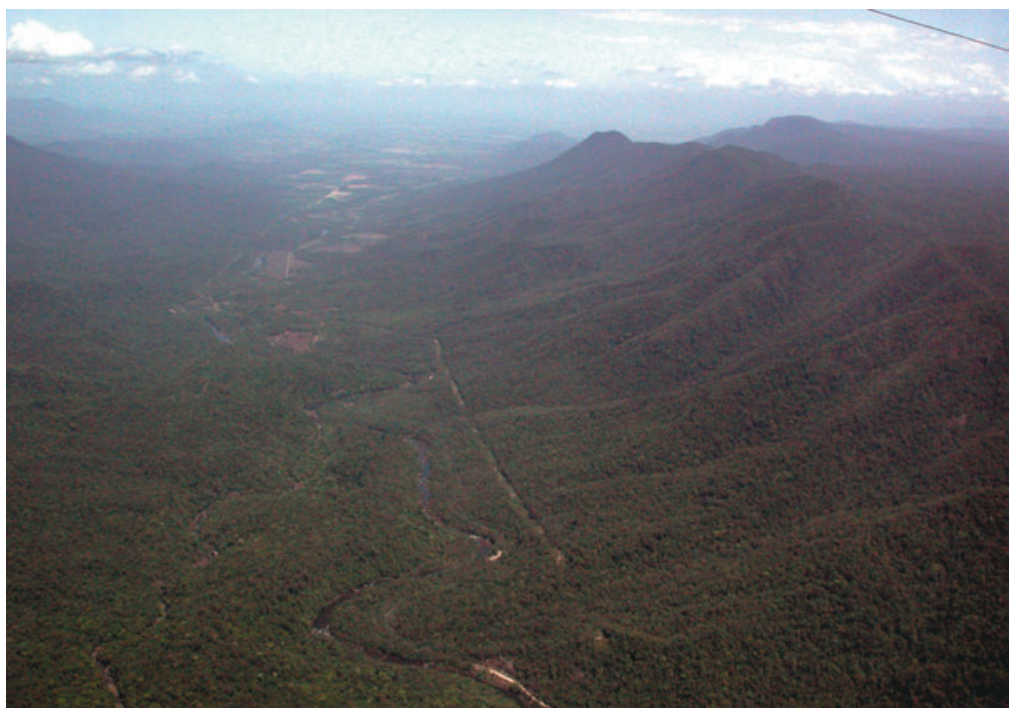

Figure 1: (a) View downstream (east) along the upper Tully River, flanked with native vegetation where it exits hilly terrain (midground), and crosses farmed coastal floodplain (distance) to flow to the coast (far distance). 
(b)

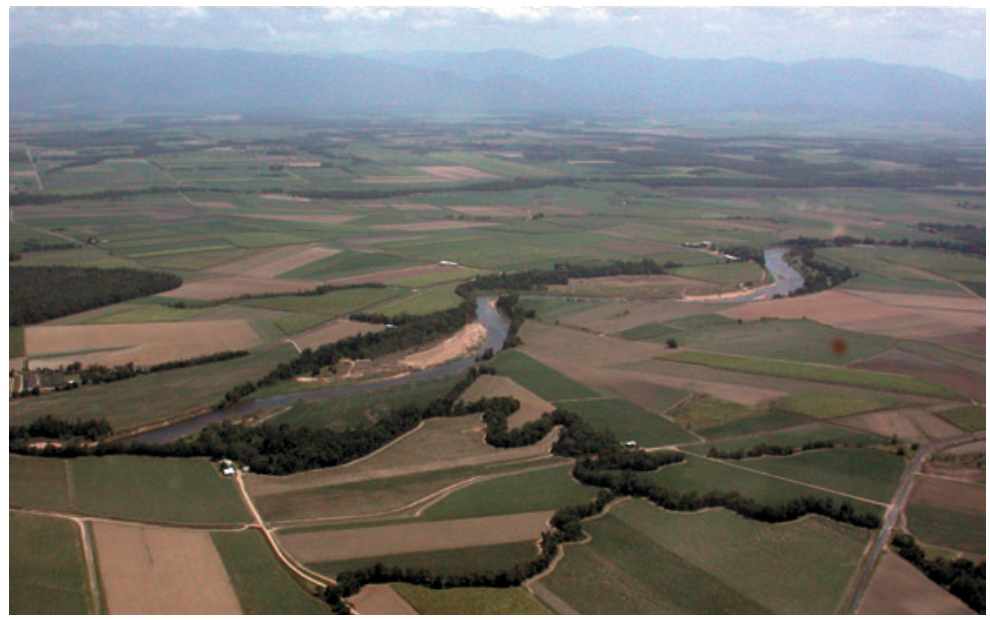

(c)

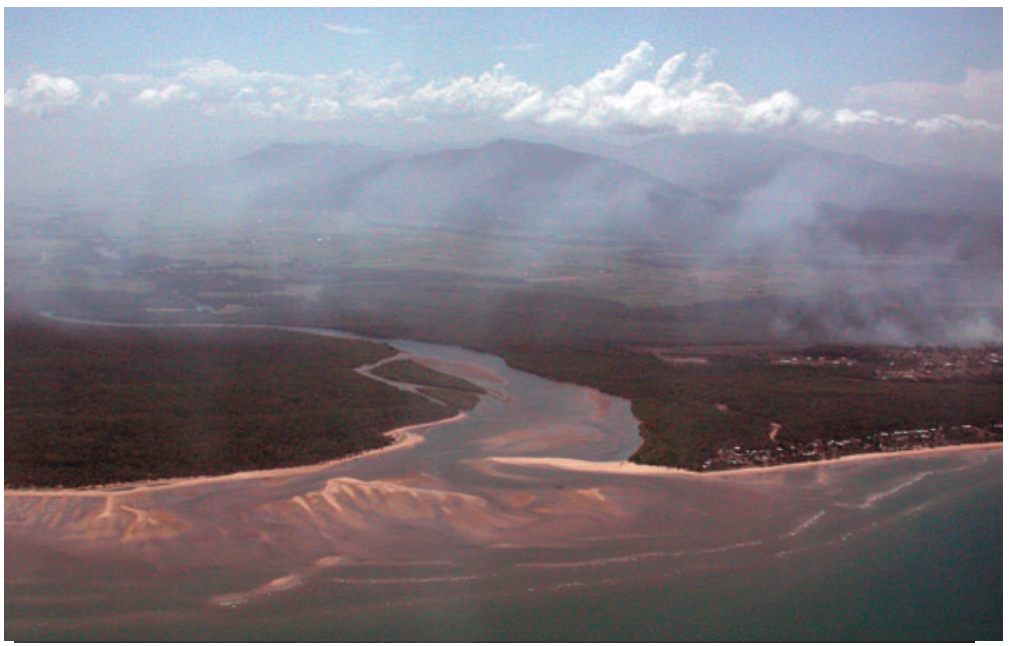

Figure 1: (b) View upstream (southwest) of the middle Tully River floodplain, near Ingham. Note intensive landuse for crops; eastern edge of the Great Dividing Range in the distance. (c) View west into the mouth of the Tully River. Note the naturally vegetated estuary, and the absence of development apart from a strip of coastal cottages on the north (right) side of the river. Sediment contributed to the coast by recent flood events comprises a series of reworked, arcuate mouth bars, and a southbuilding sand spit encloses most of the estuary mouth. 

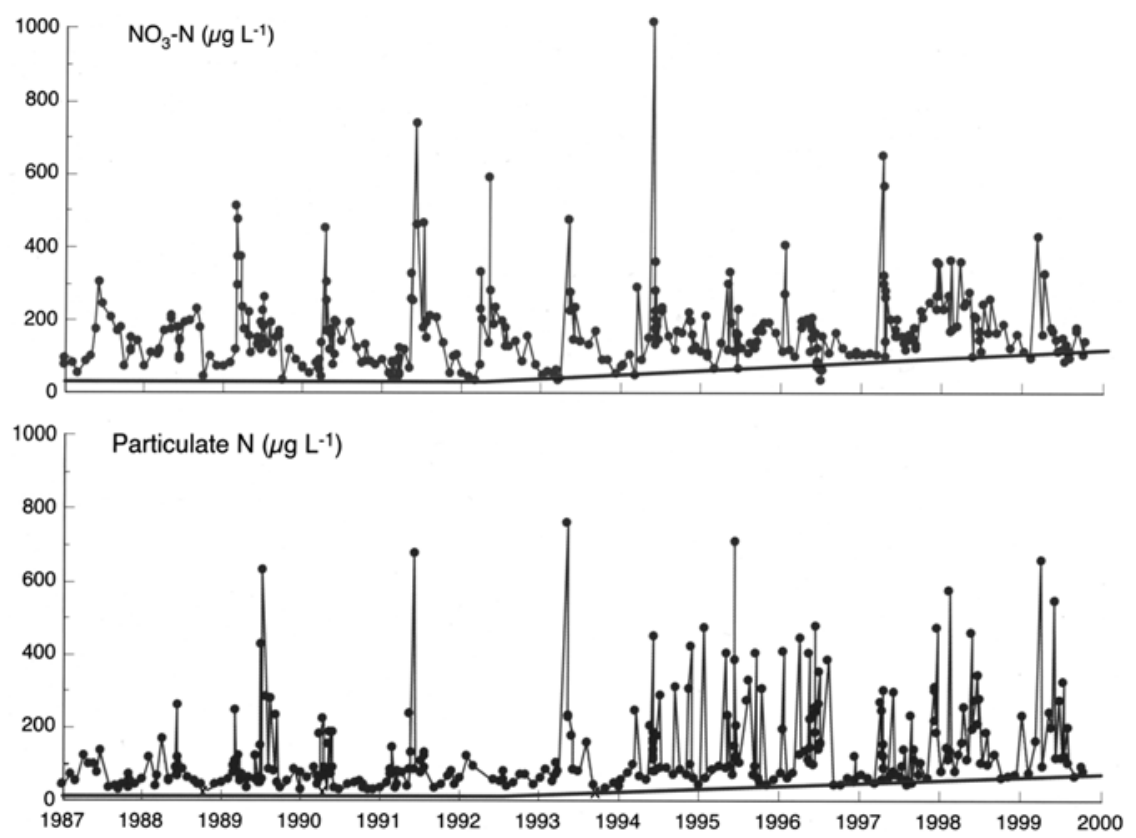

Figure 2: Nitrate (above) and particulate nitrogen (below) concentrations in the Tully River at Euramoo, 1987-2000. After Furnas [2, p. 191-192]. Trend lines fitted by eye to estimated baseflow (winter) concentrations.

\section{The Dataset}

The presence of enhanced nutrient levels in the Tully River (Fig. 2) was apparently first reported by Mitchell et al. [10], and has been discussed further by Furnas [1]. These authors present 13-year-long time-series measurements of dissolved and particulate nitrogen and phosphorus. This is the longest and most detailed dataset for nutrients which is available for any river in the GBR catchment.

Mitchell et al. and Furnas are experienced scientists, and it is therefore of course true - as they assert - that a change of pattern occurs within their nutrient measurements. The change is exhibited most clearly in the nitrate and particulate nitrogen data, but may also be present to some degree in the phosphate data.

The change in nitrate appears to comprise a step increase (approximate doubling) in dry season background value some time between 1993 and 1995, the exact point of change being obscured by the effects of the major 1994 wet season floods. Alternatively, Furnas [1, p. 190-191], without explaining the reasons why he eschews statistical treatment, or why he begins the trend line in 1993, plots an eye-fitted, increasing trend line to the inferred baseflow values on the nitrate and nitrogen graphs after 1993. Furnas also fits a similar trend to the phosphate data, despite stating clearly in the related text (p.188) that no increase in baseflow concentrations of particulate phosphorus, DON or DOP were observed. 


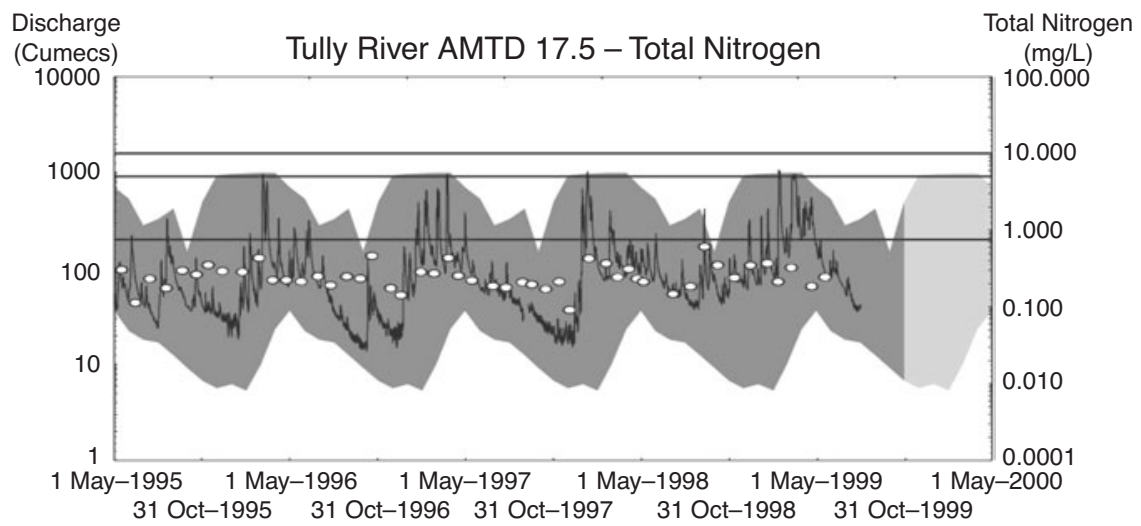

Figure 3: Total nitrogen concentrations (open circles, right hand axis) in the Tully River, $17.5 \mathrm{~km}$ from the mouth, 1995-1999, plotted together with a river flow record (continuous black line, left hand axis) and nitrogen error estimates (dark grey shading) [36; supplied courtesy Dr. J. Marohasy].

The nutrient time-series available from the Tully River are in fact too short to allow meaningful statistical testing, in view of which the fact that systematic nutrient records are apparently no longer being collected is a matter for concern. That said, and allowing for the occurrence of strong seasonal variation in river flows, no convincing trend, as opposed to a step or slight adjustment in slope, is apparent for the mean nutrient state over the measured period. Similarly, and quite independently, no recent trend towards increasing nutrient values occurs within 1995-1999 measurements for the lower Tully River collected by the Queensland Department of Natural Resources and Mines (Fig. 3).

Importantly, this lack of a trend in two independent Tully River nutrient records contrasts completely with the increasing trend of fertilizer application in GBR catchments since 1987 (Fig. 4).

\section{Alternative Explanations}

Despite the absence of a discernible longer-term trend, a small step-increase in $\mathrm{N}$-nutrient concentrations appears to have occurred at the sampling site in the lower Tully catchment between 1993 and 1995. There are many possible causes for such a change, among them:

- Step-increase in cropping activity in the Tully catchment, the application of excess fertilizer, and the discharge of the excess;

- Engineering or other public works upstream from the sampling site, which have resulted in additional nutrient flows to the river;

- A change in the pattern of environmental release of water from the Koombooloomba dam, in service of white-water rafting activities on the upper Tully River; 


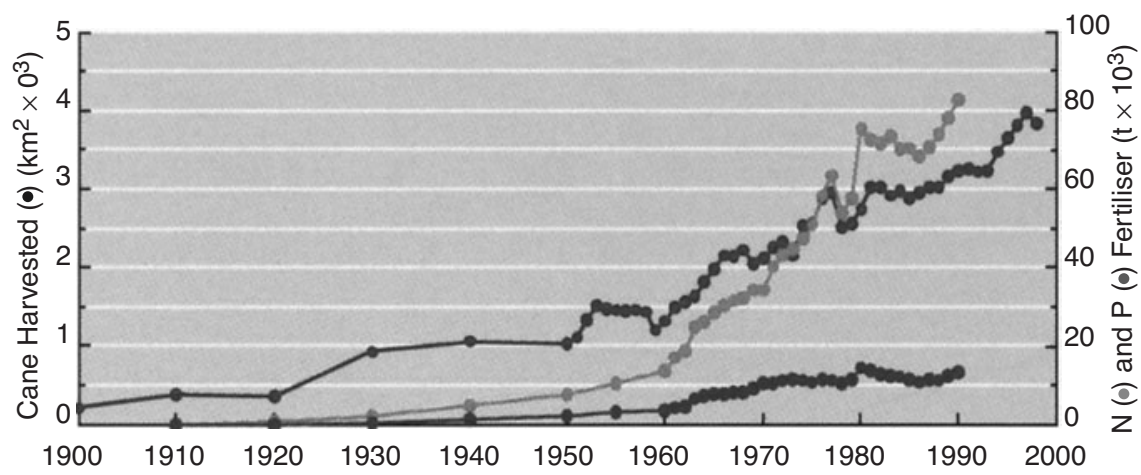

Figure 4: Area harvested for sugar cane (black circles, plotted from 1900; left hand axis) and nitrogen (grey circles, right hand axis) and phosphorus (black circles, right hand axis) fertilizer application for the GBRWHA. After CRC Reef Research Centre, Land Use and the Great Barrier Reef, June, 2003.

- Changes in rainfall and related climatic factors, with consequent changes in river flow pattern;

- Changes in the nature of supply from the groundwater aquifer into the river system, caused by natural alterations that have affected the aquifer;

- Changes in the geomorphology of the Tully River, for example consequent upon the major flood of 1994 (cyclone Sadie), whereby a new nutrient-rich sediment store has become exposed to continuing erosion; such changes are common on river flood plains; or

- Changes in the exact location, disposition or nature of the sampling instrumentation, or changes in the analytical protocols used.

The degree to which any one or a combination of these possible explanations, or others, are likely to have caused the step-change in nutrients in the Tully River can and should be debated. But such alternatives are not discussed in any detail in the publications or letters referred to above. Rather, their authors jump straight to the conclusion that the first suggested interpretation applies, i.e. that the change in nutrient measurements in the Tully River results from agricultural malpractice.

Despite this conclusion, and despite qualitative statements such as the rise in baseflow nutrient levels and increased erosion rate coincide with a change in agricultural land use in the Tully and Murray River drainage basins [1, p.188], the cropping-area and fertilizer use data provided [10] are insufficiently detailed to establish that a quantitative step-change in landuse practice occurred in the Tully catchment between 1993 and 1995. Nor is there any discussion in these references of the time-delays which apply between the agricultural application of fertilizer and the putative appearance of the same nutrients in the downstream river via groundwater flow. Lastly, also lacking is any discussion of modern best-practice farming. For example, Milford [12] has recommended that growers should apply just slightly more fertilizer than their crops have been demonstrated to take up, and Johnson et al. [13] 
have shown that, using a green cane (trash blanketing) cropping system, nutrient export from individual cells can be reduced to $0.8 \mathrm{~kg} / \mathrm{ha}$ total soluble nitrogen from as high as $3.8 \mathrm{~kg} / \mathrm{ha}$ under the now largely historic burnt cane system. Because trash blanketing is currently used by over $95 \%$ of the canegrowers located to the north of Townsville (Jennifer Marohasy, pers. comm.), it is clear that these best farming practices must have produced major reductions in nutrient outflows.

\section{Other Evidence for Changes in GBR Nutrient Status}

Because the Tully River data represented Furnas' [1] best evidence for human-related (nutrient) changes, its completely inconclusive nature raises the question as to what other evidence exists that land runoff, including either sediment or nutrient, has damaged reefs within the GBR tract? After all, there surely must be some basis in fact for remarks such as the following, which were made in 2001 in the GBRMPA Quality Action Plan [11]:

Decades of scientific research and evaluation have clearly and unequivocally established that land use activities in the catchments adjacent to the Great Barrier Reef are directly contributing to a decline in water quality.

A range of pollutants are measurable in river outflows and these are degrading the inshore ecosystems of the Reef.

Similar patterns of pollutant-related decline have led to the collapse of coral reef systems in other parts of the world.

In so far as they are grounded in reality, which is not very far, these statements seem to aim to impart an alarmist twist to innocent facts. However, remembering that the source of the opinions is a premier environmental management agency, even less acceptable is the promulgation of such direct untruths as the statement that pollutants .... ARE degrading the inshore ecosystems of the Reef.

Egged on by this type of generalized misinformation from "official" sources, it is no surprise that the current public perception is that the GBR is being damaged by land runoff. This perception has been strongly fostered by other ill-founded opinions, such as those of the Independent Science Panel which advised a Reef Protection Interdepartmental Committee during the preparation of the Reef Water Quality Protection Plan. This panel made the following assertions (italics) [14], beneath each of which I have inserted clarifying comments, as appropriate:

- Coral reefs at several inshore locations along the coast have been disturbed and remain in a disturbed state, showing characteristics consistent with impacts due to enhanced nutrient availability or sedimentation.

The only damaging disturbances documented for nearshore GBR reefs are those associated with the local, mostly physical, human impacts of urbanisation, tourism and recreation. No published scientific studies have yet demonstrated a deleterious impact on regional water quality caused by human-related sediment or nutrient yield.

- Coral reefs adjacent (to) the Wet Tropics region show significantly higher levels of most major water quality parameters (e.g. nutrients), dramatically 
lower coral cover and diversity, increased areas of abundant algae, apparent imbalances between previous reef development and current potential for reef growth (based on the absence of live corals and reduced coral recruitment), and the recent disproportionate loss of exceptionally large, ancient coral colonies (indicating recent conditions were at least temporarily worse than during past several centuries).

Studies of fringing reefs in the Whitsunday area [15] have indeed shown that these reefs exhibit less taxonomic diversity and are situated in more turbid, nutrient-rich waters than their offshore, blue-water counterparts. This status is, however, entirely expected, because (i) these reefs belong to a category which is adapted to life in nearshore, turbid-waters [16]; (ii) viable nearshore fringing reefs of this type have been growing in the zone of coastal terrigenous influence for at least the last 5,500 years [17]; and (iii) over the same period, a slowly falling sea-level has progressively exposed most reef flats, causing mortality in shore-parallel zones along their inner part and often leading to the development of a "dead" reef flat [18].

No case exists, therefore, for anthropogenic reef degradation in these or other similar studies. In fact, rather than degradation, studies of coral cores that reach back to the 1400s show that during the 20th century Porites growth rates have increased by an average of $4 \%$ across the GBR shelf, including in corals located on the inner shelf [19].

Finally, no reputable, refereed scientific paper that I am aware of has established the existence of an imbalance between inshore GBR reef development and current 'reef growth potential', nor of any human-caused water quality damage, disproportionate or otherwise, to large, ancient coral colonies.

- The concentrations of nutrients in river plumes may cause harm to GBR ecosystems.

No quantitative information is provided as to the actual levels of nutrients that are considered dangerous. No evidence is cited, nor exists to date, that the concentrations of nutrients in modern GBR coastal river plumes exceed preEuropean natural concentrations [20]. Furthermore, particulate nutrients undergo similar dispersal to terrigenous sediments which, over longer periods of time, are advected shorewards to accrete within the shore-connected sediment prism [21]. Offshore reefs are obviously unaffected by such inputs, and although inshore reefs are tolerant of high turbidity and sediment supply, in general they do not grow in the immediate vicinity of the major shoreline depocentres that host the bulk of the particulate nutrients.

Anything 'may' be possible, but it remains undemonstrated and extremely unlikely that human-caused nutrient enhancement currently has any negative regional impact on GBR ecosystems.

Though the italicized statement above may seem anodyne, that very fact makes it difficult to see that it can have any other purpose than to raise unnecessary alarm.

- There are detectable levels of herbicides (principally diuron) in coastal and intertidal sediments and seagrasses adjacent to catchments with high agricultural use, at levels potentially impacting on the health of seagrasses. 
Whether a man-made chemical is detectable in the environment or not is a function of the sensitivity of the analytical instrumentation used; this sensitivity has greatly improved over the last several decades. Extensive recent surveys have been undertaken within the GBRWHA for the presence of organochlorine herbicides and insecticides [22]. Estuarine and nearshore marine sediments have been the most intensively sampled, on the assumption that these areas are likely to contain the highest concentration of any contaminants from nearby catchments. Noting that a small number of isolated water samples collected during a flood event on the Pioneer River had elevated values of pesticides [23], regionally only trace amounts of organochlorines have been found in GBR sediments and then only in the vicinity of a small number of river mouths. That it has taken so long before measurable amounts of chemicals were detected, and that they are present only rarely and at such low levels, creates a strong prima facie expectation that they are unlikely to be damaging. It seems probable that organochlorines are rapidly degraded after they enter the marine environment, for example by microbial reduction [24].

In any case, this statement by the Science Panel gives no indication of (i) what actual levels of what chemicals were detected; (ii) what levels are demonstrated to be damaging, as opposed to having the 'potential' to damage; and (iii) in no case have any agricultural chemicals been detected on the GBR itself, let alone in damaging amounts.

- There is evidence from overseas demonstrating harmful effects of excess nutrients and sedimentation on reef systems. This evidence also shows that by the time widespread effects are obvious, the system would be almost irreparably damaged.

The GBR is $2,000 \mathrm{~km}$ long, contains several thousand individual reefs, is situated next to a landmass with an extremely low population density, and is not depended upon by Queensland coastal communities for their very subsistence [8]. The most badly damaged overseas reefs, as in Southeast Asia and the Caribbean, are located adjacent to high density population centres, and are also heavily exploited for their food and other resources. To depend upon drawing speculative parallels between such reefs and the GBR serves merely to highlight the lack of other evidence that any substantial human damage has yet been inflicted on the GBR.

Given the robust natural resilience of coral reef communities, it is also entirely unclear why any reef would be irreparably damaged by the time that the effects of that damage were obvious. Wood [25] has pointed out that there is an enormous ecological redundancy of species in reefs and that modern coral reefs are a mosaic where organisms show the whole range of life histories designed to cope with fundamentally differing degrees of disturbance. Reefs on new substrates, or those destroyed during cyclones, start to regrow within a few months, and can be well on the way to recovery to a 'climax' community within 5 years [26].

I have given the Tully nutrient data credence for the purposes of the earlier discussion because (i) they are quantitative, despite the shortness of the time-series; and 
(ii) they are most consistent with a lack of human impact on the system. However, even should a human-enhanced nutrient supply be demonstrated in future, it is as likely to be beneficial to shelf communities as harmful (see below). Both this likelihood, and the existing Tully River data, stand in marked contrast to the vague, qualitative, alarmist views reported above.

In addition to the 13 year-long riverine nutrient record from the Tully River, the available modern nutrient data for GBR shelf waters up to 2000 were summarised by GBRMPA [5]. These data exhibit high interseasonal and interannual variability (Fig. 7). There are no significant long-term trends over the past decade for phosphate, nitrate or suspended sediment, nor for chlorophyll since 1976 (cf. Fig. 4).

Realistically, however, for behaviour as variable as that of tropical river flow [27, 28 , where annual variability can reach several orders of magnitude, data time-series at least 40 and preferably 100 years long will be needed to detect small changes which might occur. In the North Queensland context, this inevitably requires the use of proxy indicators rather than direct measurements, such as the 200-year long coral cores described by McCulloch et al. [29]. Significantly, proxy indicators from these cores do not record a significant increase of nutrient input over recent years. Furthermore, the very existence of such long-lived, healthy corals in nearshore waters is in itself strong prima facie evidence of their adaptation to life in turbid coastal water.

\section{Environmental Significance of Enhanced Nutrients}

Given the likelihood that a modest step-increase in dry season nutrient concentration in the Tully River occurred in 1994, a key question that needs addressing is whether or not this increase, irrespective of its cause, is damaging to the environment (Figs. 5, 6).

This question is not discussed at all by the authors of the papers referred to earlier, nor in the letters sent to their constituents by Minister Kemp or Premier Beattie.

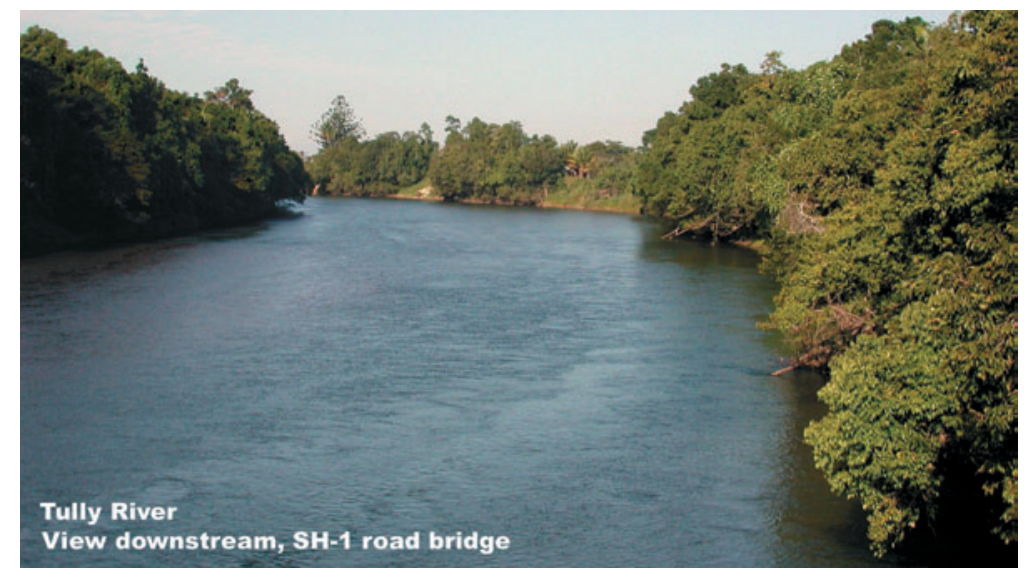

Figure 5: Tully River, view downstream from the State Highway 1 bridge during dry season (low flow conditions). Note clean water and healthy riparian vegetation. 


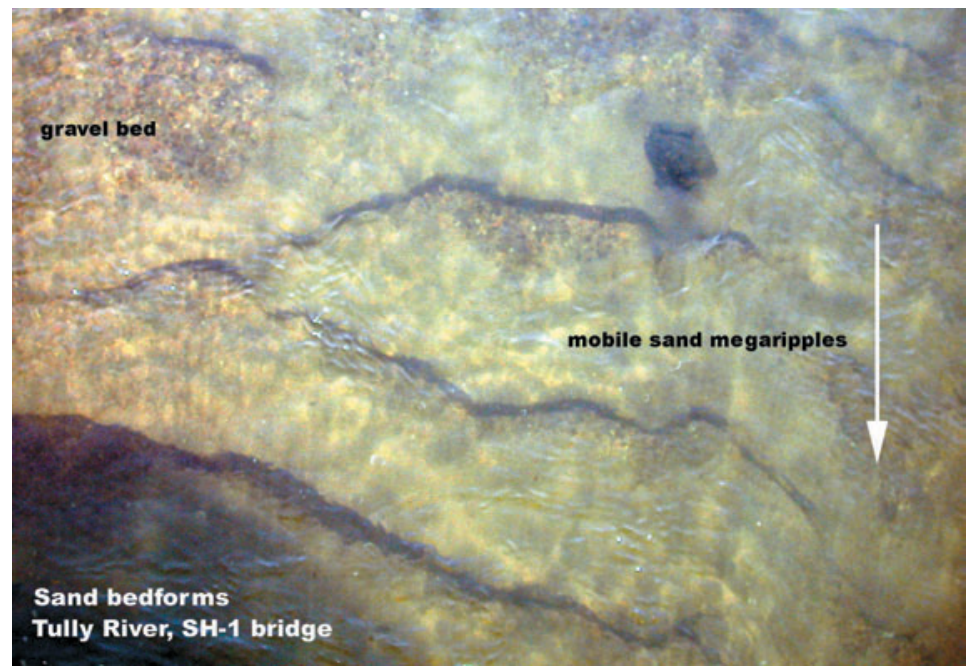

Figure 6: Tully River, State Highway 1 bridge, vertical view towards river bed during the dry season. Note the sparkling water clarity, such that low-flow sand ripples with granule-filled troughs are clearly visible.

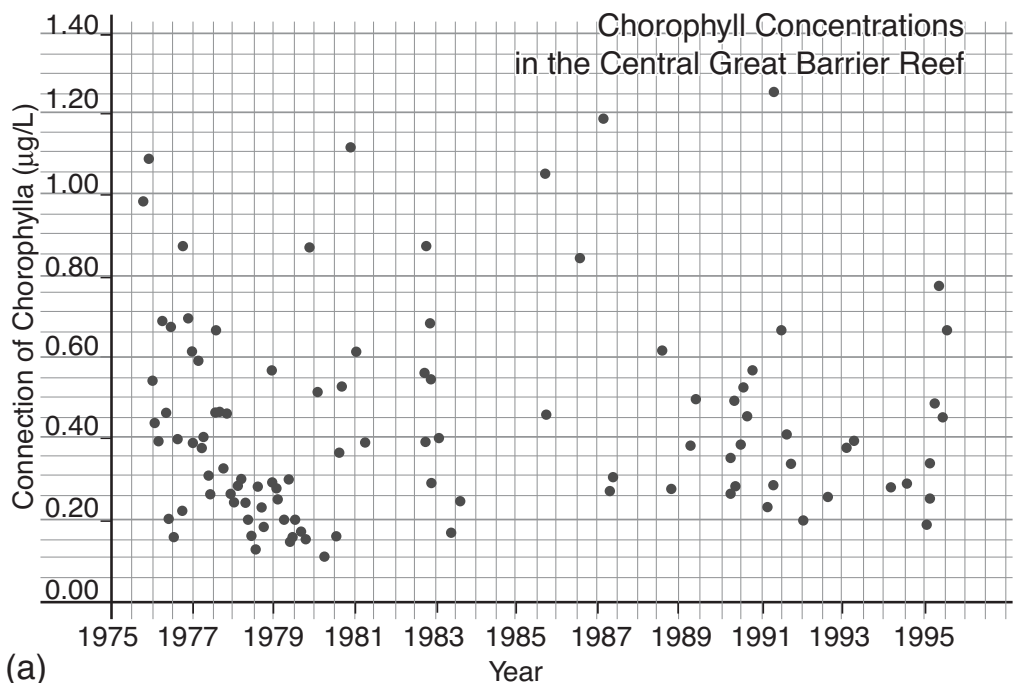

Figure 7: Nutrient measurements for GBR shelf waters, after GBRMPA [5]. Note the strong seasonal variability, and the absence of significant long term trends. (a) Chlorophyll, 1976-1996; 


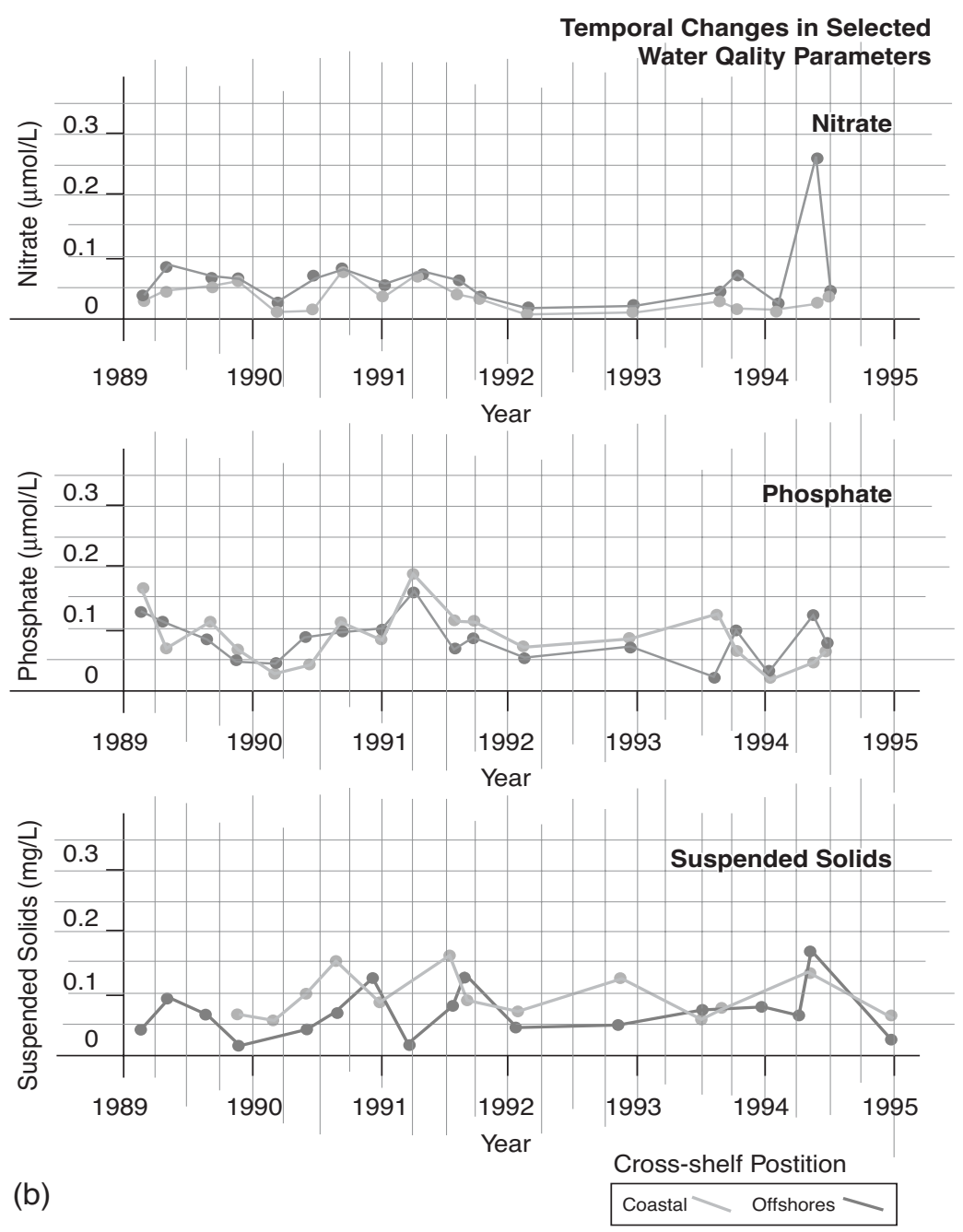

Figure 7: (b) Nitrate, phosphate and suspended solids, 1989-1994.

Rather, all these persons presume it to be axiomatic that increased nutrients equate with environmental damage.

The following issues are relevant:

- Problematic eutrophication events have not been described from the Tully River;

- Abnormally large algal marine plankton blooms have not been reported in nearby marine waters during or shortly after Tully River flood events, and even should they occur they will not necessarily be damaging;

- Despite the occurrence of "enhanced" nutrient levels in the Tully River since 1995, 13-year (1987-2000) mean nutrient values for the lower river lie within 

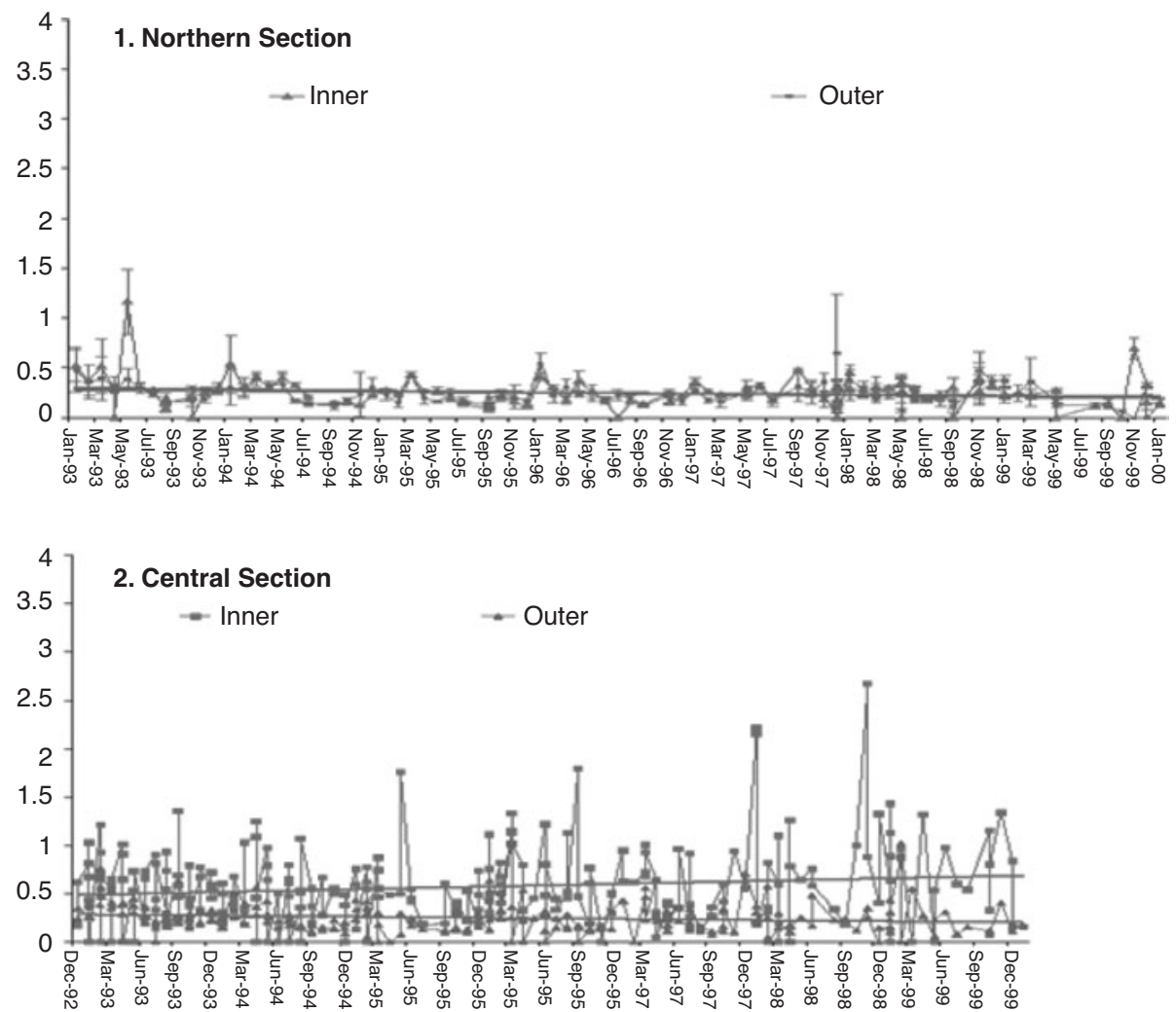

(c)

Figure 7: (c) Chlorophyll, 1992-1999,

the envelope of mean nutrient measurements from 16 regionally-distributed Queensland river sampling sites, as reported by Furnas [1, p.178];

- Given that water volumes, and hence total nutrient content, are greatly increased during flood events from wet tropical rivers (Fig. 8), a single adventitious wet season flood from the Tully River can discharge as much nutrient into the marine environment as a 20-year or more supply of "enhanced" dry season nutrient from the same river; far from having an adverse effect on the GBRWHA, such nutrient supplies are vital for the sustenance of GBR shelf ecosystems [1, p. 31];

- Coastal houses built on the foreshore sand ridge immediately north of the Tully River mouth (Fig. 9a), which is the regional down-drift side, have had to be protected over recent years by the insertion of an unsightly wall of rip-rap along their eroding beach front (Fig. 9b); in March 2004, some $1500 \mathrm{~m}^{3}$ of foredune sand was stripped from the coastal side of a caravan park situated just north of the end of the sea-wall (Fig. 9c); though this particular bout of erosion 


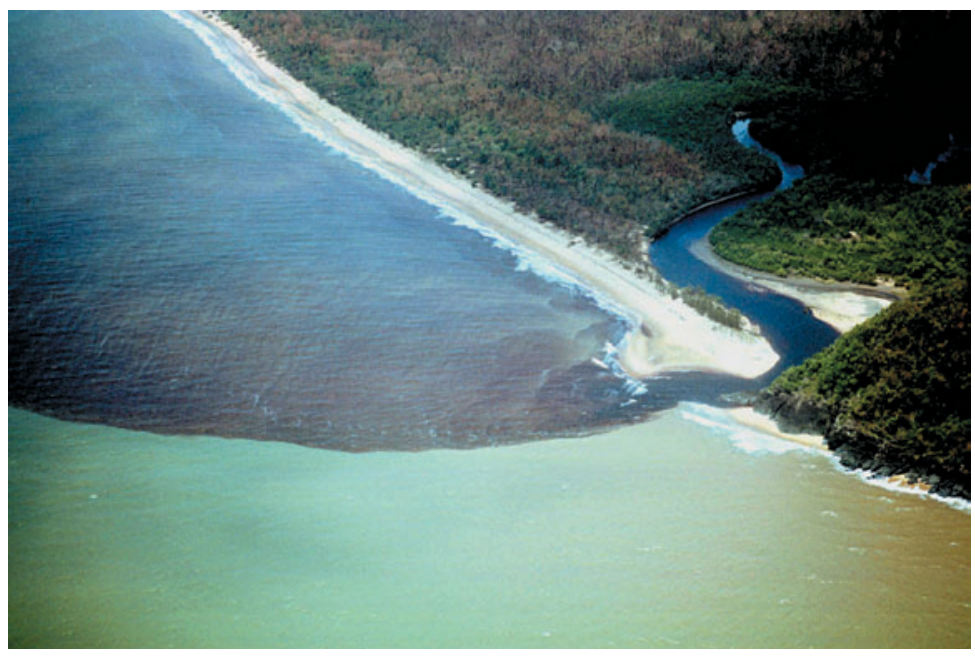

Figure 8: Post-cyclone flood plume exiting onto the Great Barrier Reef shelf from a north Queensland coastal creek with natural vegetation catchment. The rich organic content of the plume represents a vital, episodic source of new nutrients for the diverse ecosystems of the GBR inner shelf.

may relate to shifting dynamics at the river mouth, the situation overall is suggestive of a deficit rather than a surfeit of sediment (and accompanying particulate nutrients) in the Tully-supplied coastal sand budget;

- Nutrient levels on the GBR shelf are nearly everywhere low with respect to worldwide averages, and eutrophication does not exist [30]. Because of the low nutrient status of much of the GBR water mass, it is likely that any significant introductions of nutrients into shelf waters would be quickly manifested in the growth of regional phytoplankton populations and their removal through grazing and sedimentation [31]; in other words, modest increases in nutrient supply to the shelf, be they anthropogenic or natural, will have a beneficial effect on both productivity and biodiversity, with little if any effect on reefs;

- Even should as yet undetected human nutrient enrichment act to encourage algal bloom and potential overgrowth of corals on particular reefs, experimental work has shown that the presence of normal populations of grazing fish is adequate to control algal infestation [32]; and lastly

- Despite more than 30 years of detailed research, not a single undisputed case exists of substantial harm to a GBR coral reef from regional nutrient or sediment poisoning; therefore, and given the natural variability of the nearshore GBRWHA ecosystems in both space and time, it is simply implausible to suggest that the current level of nutrient or sediment outflow from North Queensland rivers, the Tully included, poses a widespread environmental threat [33]. 
(a)

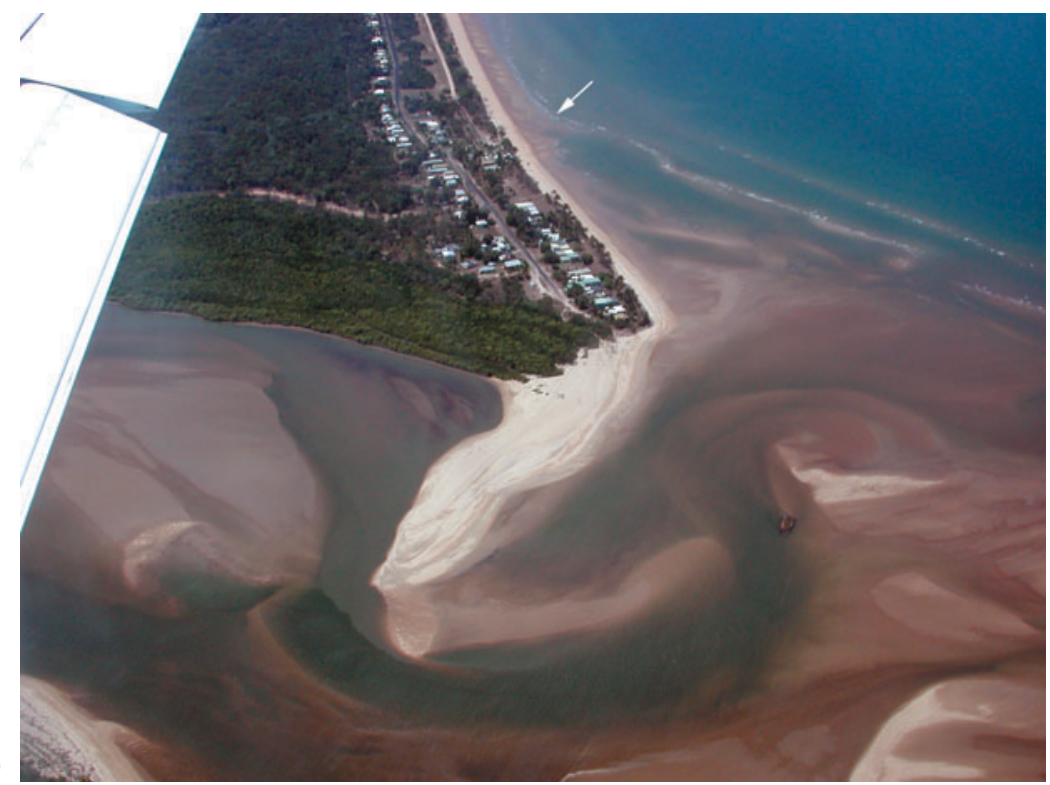

Figure 9: (a) Aerial view of Tully River mouth from above its south bank. The regional direction of coastal transport, under the influence of southeasterly trade winds, is to the north (top left diagonal in the picture). The southerly-directed sand spit which closes much of the mouth has been built by waves that are locally refracted southwards by the presence of nearshore mouth sand bars (cf. Fig. 1c). Storm wave runup in early 2004 was concentrated a few hundred metres north of base of the spit, just north of a protective rip-rap wall, and caused extensive beach and foredune erosion near the point where the Tully offshore mouth bar curves northward to merge into the beach (white arrow).

\section{Happy Days}

Most rivers that debouch onto the GBR shelf are small, and possess low volume flows apart from brief, intermittent flood events in summer. The Tully River drains the wettest region in Australia and its lower reaches are surrounded by a relatively large agricultural area by local standards. It represents a likely "worst case" situation for possible nutrient pollution.

The above discussion has shown that the evidence that Tully River nutrient concentrations are significantly enhanced by human activity is completely inconclusive. That Furnas [2, p.188] and others consider the Tully River nutrient figures as the strongest evidence available for anthropogenic damage to the GBR is therefore very good news indeed for the health of the Queensland environment.

Similarly, no evidence exists either for an increasing nutrient trend in GBR marine waters generally (Fig. 7). Importantly, the enhanced dry season nutrient levels reported in the Tully since 1993-94 lie within the range of background values for the region. Extra nutrients or sediments of post-European origin are in fact more likely to benefit 
(b)

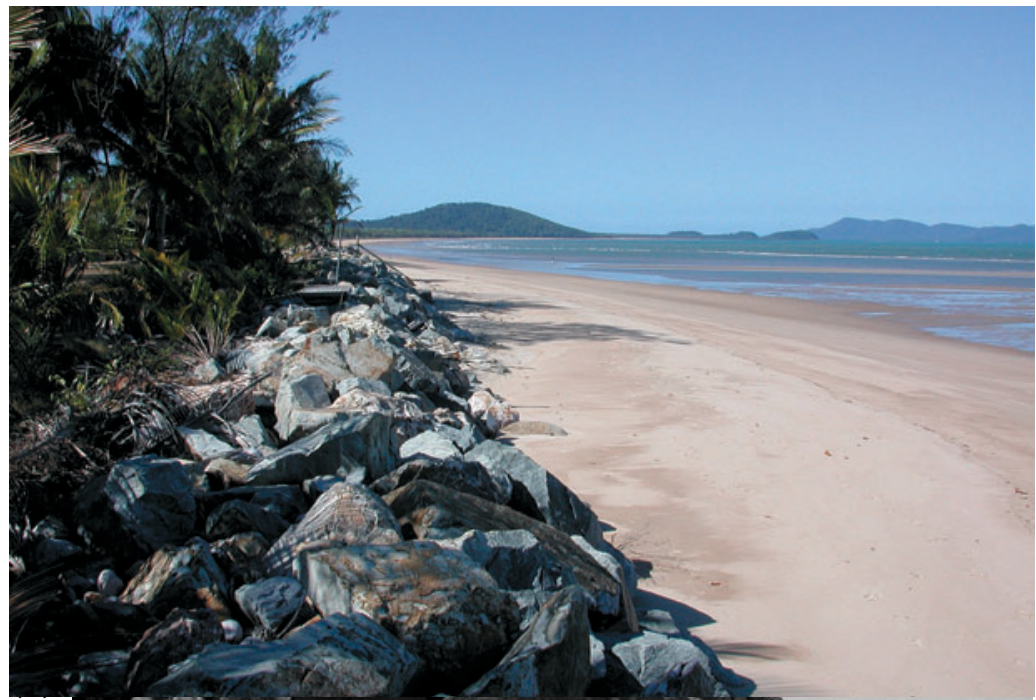

(c)

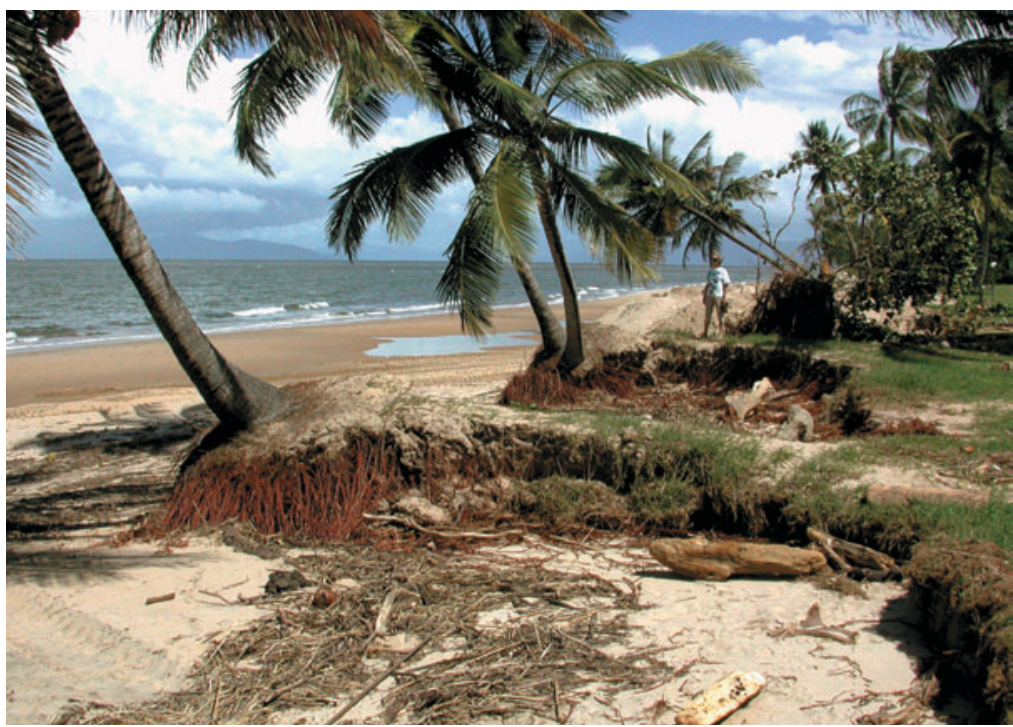

Figure 9: (b). View north along the foredune protective riprap wall that runs for about $150 \mathrm{~m}$ north from the base of the Tully River mouth spit. The distant breaker line which passes from picture right to picture far mid centre marks the northward swinging edge of the river mouth offshore bar (cf. Figs. 1c, 9a); (c) View south along eroded foredune edge and toppled palm trees, shortly after the March, 2004 storm which caused severe coastal erosion in this vicinity. 
than harm the GBRWHA, and are anyway insignificant in the context of the regional nutrient budget and the seasonal variations which occur within it.

The Queensland Government's 2003 Reef Water Quality Protection Plan [2], according to another recent document on planning for climate change [34], should improve the reef's water quality and its resilience to climate change. It is, of course, certain that the production of reports and plans of this type carries great political benefit. It is also certain that the money spent on such exercises, and on related contrived public "focus discussions" and research prioritisation, will result in no measurable improvement in regional water quality, nor add to the resilience of the Great Barrier Reef to climate change.

All mature ecosystems, and major reef systems in particular, derive their stability from multifarious homoeostatic mechanisms that have developed naturally over hundreds of millions of years of environmental change and evolution. As Hughes \& Connell [35] have commented corals and other reef organisms have evolved complex regenerative mechanisms which allow them to recover from a host of natural mortality sources. It is human hubris of the worst kind to presume to "manage" such large, dynamic natural systems as the GBRscape on the basis of the limited understanding that we presently possess, and particularly so in the absence of hard evidence for regionally damaging anthropogenic impacts.

Improvement of tourism, and urban and land management practices in Queensland to minimize harm to the environment is a desirable aim which undoubtedly commands wide public support. However, government regulation toward such improvements should be based on knowledgeable and objective analysis of the available science, and justified on a case-by-case basis. Policy which is based instead on mischievous claims of chimerical damage to the Great Barrier Reef will ultimately cause more damage than good.

\section{ACKNOWLEDGEMENTS}

This research was supported by funds granted by the Australian Research Council, under grant DP 0344080. I thank Professor Mal Heron for supporting my participation in an aerial overflight of the Tully River, and Jennifer Marohasy, Walter Stark, Peter Ridd and Piers Larcombe for much valuable discussion, and, together with an anonymous referee, for making constructive suggestions towards improving the manuscript.

\section{REFERENCES}

[1] Furnas, M.J., 2003. Catchments and Corals. Terrestrial Runoff to the Great Barrier Reef. AIMS, Townsville, 334 pp.

[2] Australian Government \& Queensland Government, 2003. Reef water quality protection plan for catchments adjacent to the Great Barrier Reef World Heritage Area. http://www.gbrmpa.gov.au/corp_site/key_issues/water_quality/rwqpp.pdf

[3] Baker, J.T., 2003. A report on the study of land-sourced pollutants and impacts on water quality in and adjacent to the Great Barrier Reef. Intergovernmental Steering Committee, GBR Water Quality Action Plan, Premier's Department, Queensland Government, Brisbane, 1-187.

[4] Productivity Commission, 2003a. Industries in the Great Barrier Reef Catchment \& Measures to Address Declining Water Quality. Draft Research Report, 306 pp. 
Productivity Commission, 2003b. Industries, land use and water quality in the Great Barrier Reef Catchment. Research Report, 415 pp. http://www.pc.gov.au/study/gbr/ finalreport/index.html.

[5] GBRMPA, 2001. Great Barrier Reef Water Quality, Current Issues. Great Barrier Reef Marine Park Authority, Townsville. http://www.gbrmpa.gov.au/corp_site/key_issues/ water_quality/current_issues/wq_report $\overline{98-a u g 01 . p d f}$

[6] Eyre, B., 1993. Nutrients in sediments of a tropical north-eastern Australian estuary, catchment and nearshore coastal zone. Australian Journal of Marine \& Freshwater Research 44, 845-866.

[7] Sweatman, H., Osborne, K., Smith, L., Grubba, T., Kinch, J., Jones, G. \& Rai, V., 2002. Status of coral reefs of Australasia: Australia and Papua New Guinea. In: Wilkinson, C. "Status of the Coral Reefs of the World 2002", Australian Institute of Marine Science, Townsville, pp.163-180.

[8] Starck, W. 2005 'Threats' to the Great Barrier Reef. IPA Backgrounder, Institute of Public Affairs, Melbourne, http://ipa.org.au/publications/publisting_detail.asp?pubid=414.

[9] Marohasy, J. \& Johns, G. 2002 WWF says 'jump!', governments ask 'how high?'. Occasional Paper, Institute of Public Affairs, 16 pp., http://ipa.org.au/publications/ publisting_detail.asp? pubid=347.

[10] Mitchell, A.W., Reghenzani, J.R. \& Furnas, M.J., 2001. Nitrogen levels in the Tully River a long term view. Water Science \& Technology 43, 99-105.

[11] GBRMPA, 2001. Great Barrier Reef Water Quality Action Plan. A Report To Ministerial Council on targets for pollutant loads. http://www.gbrmpa.gov.au/corp_site/key_issues/ water_quality/action_plan.

[12] Milford, B. 1998. Reduce inputs, reduce off-farm impacts and increase profits. Sugar Environment Forum, 24-25th March, 56-66. Canegrowers Organisation Ltd., Brisbane.

[13] Johnston, A., Walker, D. \& Wood, A. 1997. Spatial analysis of the impact of land use on nutrient loads in the Herbert River catchment. Sugar Research \& Development Corporation, Final Report - Project CSC13S, 1-90.

[14] Independent Science Panel of the Reef Protection Interdepartmental Committee, 2001. Water quality, from catchment to reef, 2001. http://www.reeffutures.org/topics/ waterquality.cfm.

[15] Van Woesik, R. \& Done, T.J., 1997. Coral communities and reef growth in the southern Great Barrier Reef. Coral Reefs 16, 103-115.

van Woesik, R., Tomascik, T. \& Blake, S., 1999. Coral assemblages and physico-chemical characteristics of the Whitsunday Islands: evidence of recent community changes. Marine \& Freshwater Research, 50, 427-440.

[16] Anthony, K.R.N., 2000. Enhanced particle-feeding capacity of corals on turbid reefs (Great Barrier Reef, Australia). Coral Reefs 19: 59-67.

Larcombe, P. \& Woolfe, K.J., 1999. Increased sediment supply to the Great Barrier Reef will not increase sediment accumulation at most coral reefs. Coral Reefs 18, 163-169. 
Potts, D.C. \& Jacobs, J.R., 2003. Evolution of reef-building scleractinian corals in turbid environments: a paleo-ecological hypothesis. In: $9^{\text {th }}$ International Coral Reef Symposium (Bali, October 2000), Proceedings, 249-254.

Smithers, S. \& Larcombe, P., 2003. Late-Holocene initiation and growth of a nearshore turbid-zone coral reef: Paluma Shoals, central Great Barrier Reef, Australia. Coral Reefs, 22, 499-505.

[17] Johnson, D.P. \& Risk, M.J., 1987. Fringing reef growth on a terrigenous mud foundation, Fantome Island, central Great Barrier Reef. Sedimentology 34, 275-287.

[18] Chappell, J., Chivas, A., Wallensky, E., Polach, H.A. \& Aharon, P., 1983. Holocene paleoenvironmental changes, central to north Great Barrier Reef inner zone. Bureau of Mineral Resources Journal of Australian Geology and Geophysics 8, 223-236.

Johnson, D.P. \& Carter, R.M., 1987. Sedimentary framework of mainland fringing reef development, Cape Tribulation area. Great Barrier Reef Marine Park Authority, Technical Memorandum 14, 37 pp.

[19] Lough, J.M. \& Barnes, D.J., 2000. Environmental control on growth of the massive coral Porites. Journal of Experimental Marine Biology \& Ecology 245, 225-243.

[20] Devlin, M.J. \& Brodie, J., 2005. Terrestrial discharge into the Great Barrier Reef lagoon: nutrient behaviour in coastal waters. Marine Pollution Bulletin 51, 9-22.

[21] Orpin, A.R., Ridd, P.V. \& Stewart, L.K., 1999. Assessment of the relative importance of major sediment-transport mechanisms in the central Great Barrier Reef lagoon. Australian Journal of Earth Sciences 46, 883-896.

[22] Cavanagh, J.E., Burns, K.A., Brunskill, G.J. \& Coventry, R.J., 1999. Organochlorine pesticide residues in soils and sediments of the Herbert and Burdekin River regions, north Queensland - implications for contamination of the Great Barrier Reef. Marine Pollution Bulletin 39, 367-375.

Haynes, D., Ralph, P., Prange, J., \& Dennison, W., 2000. The impact of the herbicide diuron on photosynthesis in three species of tropical seagrass. Marine Pollution Bulletin 41, 2 288-293.

Prange, J.A., Gaus, C., Papke, O. \& Muller, J.F., 2002. Investigations into the PCDD contamination of topsoil, river sediments \& kaolinite clay in Queensland, Australia. Chemosphere 46, 1335-1342.

[23] Department of Natural Resources \& Mines (DNRM), 2002. River water quality in the the Pioneer catchment on February 14-15, 2002. Report issued 2 July, Queensland Government, $11 \mathrm{pp}$.

[24] Bunge, M., Adrian, L., Kraus, A., Opel, M., Lorenz, W.G., Andreesen, J.R., Gorisch, H. \& Lechner, U., 2003. Reductive dehalogenation of chlorinated dioxins by an anaerobic bacterium. Nature 421, 357-360.

[25] Wood, R. 1999 "Reef Evolution”. Oxford University Press, 414 pp.

[26] Loya, Y., 1990. Changes in a Red Sea coral community structure: a long-term case history study. In: Woodwell, G.M. (ed.), "The Earth in Transition: Patterns and Processes of Biotic Impoverishment”, Cambridge, pp. 369-384. 
Tomascik, T., van Woesik, R. \& Mah, A. 1996 Rapid coral colonisation of a recent lava flow following a volcanic eruption, Banda Islands, Indonesia. Coral Reefs 15, 169-175.

[27] Mitchell, A.W. \& Furnas, M.J., 1996. Terrestrial inputs of nutrients and suspended sediments to the GBR lagoon. In; "The Great Barrier Reef - Science, Use and Management. Reef CRC, GBRMPA and JCU, Townsville, pp. 59-71.

[28] Mitchell, A.W., Bramley, R.G.V. \& Johnson, A.K.L., 1997. Export of nutrients and suspended sediment during a cyclone-mediated flood event in the Herbert River catchment, Australia. Marine \& Freshwater Research 48, 79-88.

[29] McCulloch, M., Fallon, S., Wyndham, T., Hendy, E., Lough, J. \& Barnes, D., 2003. Coral record of increased sediment flux to the inner Great Barrier Reef since European settlement. Nature 421, 727-730.

[30] Ulman, W.J. \& Sandstrom, M.W., 1987. Dissolved nutrient fluxes from nearshore sediments of Bowling Green Bay, Central Great Barrier Reef Lagoon (Australia). Estuarine, Coastal \& Shelf Science 24, 289-303.

Lourey, M.J., Alongi, D.M., Ryan, D.A.J. \& Devlin, M.J., 2001. Variability of nutrient regeneration rates and nutrient concentrations in surface sediments of the northern Great Barrier Reef shelf. Continental Shelf Research 21, 145-155.

[31] Furnas, M. J., 1990. The nutrient status of Great Barrier Reef waters. In: Yellowlees, D. (ed.), "Land Use Patterns and Nutrient Loading of the Great Barrier Reef Region”, James Cook University, pp.162-179.

[32] Hatcher, B.G. \& Larkum, A.W.D., 1983. An experimental analysis of factors controlling the standing crop of the epilithic algal community on a coral reef. Journal of Experimental Marine Biology and Ecology 69, 61-84.

[33] Larcombe, P. \& Woolfe, K.J., 1999. Increased sediment supply to the Great Barrier Reef will not increase sediment accumulation at most coral reefs. Coral Reefs 18, 163-169.

[34] The State of Queensland (Department of Natural Resources \& Mines), 2005. Climate Smart Adaptation. What does climate change mean for you? http://www.epa.qld.gov.aul environmental_management/sustainability/greenhouse_and_climate_change/climate_smart_ adaptation.

[35] Hughes, T.P. \& Connell, J.H., 1999. Multiple stressors on coral reefs: a long term perspective. Limnology \& Oceanography 44, 932-940.

[36] Wilhelm, G. (ed.) 2001. Water quality report for catchments containing sugar cane in Queensland, 1 May 1995 - 30 April, 2000. Queensland Natural Resources and Mines Water Quality Monitoring Group. 